\title{
FAKTOR-FAKTOR SOSIAL EKONOMI YANG MEMPENGARUHI KEBERHASILAN PRODUKTIVITAS PETANI PADI SAWAH DI DESA SELING KECAMATAN TABIR KABUPATEN MERANGIN
}

\author{
SOCIAL ECONOMIC FACTORS THAT AFFECT THE SUCCESS OF \\ PRODUCTIVITY OF FARMERS IN SELING VILLAGE, TABIR DISTRICT \\ MERANGIN DISTRICT
}

\author{
M. Radi Yusmel, Evo Afrianto and Fikriman \\ Agriculture Faculty Agribusiness Study Program \\ Muara Bungo University \\ evo_juventini@yahoo.com, manfikri@ymail.com
}

\begin{abstract}
ABSTRAK
Penelitian ini bertujuan untuk mengetahui produktivitas, tingkat sosial ekonomi dan pengaruh pengaruh faktor sosial ekonomi terhadap keberhasilan produktivitas petani padi sawah di Desa Seling Kecamatan Tabir Kabupaten Merangin. Penelitian dilaksanakan di desa Seling Kecamatan Tabir Kabupaten Merangin. Pemilihan lokasi penelitian ini dilakukan secara sengaja (purposive sampling) dengan pertimbangan bahwa desa Seling adalah desa dengan tingkat keberhasilan produksi padi sawah yang paling tinggi dibandingkan dengan desa lain di Kecamatan Tabir Dan penelitian dilaksanakan dari bulan Juli sampai Agustus 2018.

Penelitian Metode yang digunakan dalam penelitian ini adalah metode Survei, yaitu peneliti meneliti karakteristik atau hubungan sebab akibat antar variabel tanpa adanya intervensi peneliti yang dilakukan dengan beberapa tahapan penelitian, yakni pengumpulan data hasil survei, analisis data dan pengujian hipotesis, serta menarik kesimpulan. Penarikan petani sampel dilakukan secara proporsional random sampling sebesar $10 \%$ dari 276 petani padi sawah yaitu 28 orang petani padi sawah. Adapun metode analisis data dalam penelitian ini adalah dengan menggunakan rumus produktivitas dan dengan memberikan pertanyaan yang dijawab oleh responden dan skor yang diberikan berbeda untuk setiap jawaban yang tersedia sedangkan untuk mengetahui hubungan faktor sosial ekonomi dengan produktivitas maka digunakan metode analisis regresi linier berganda dengan menggunakan program SPSS.

Hasil penelitian menunjukan Produktivitas petani padi sawah di Desa Seling Kecamatan Tabir Kabupaten Merangin adalah 1.996,44 Kg/Ha $(1,99$ ton/Ha) dengan luas lahan rata-rata $0,5 \mathrm{Ha}$ dan menghasilkan rata-rata produksi sebanyak $1.001,79 \mathrm{Kg}$, sedangkan ingkat sosial ekonomi petani padi sawah di Desa Seling Kecamatan Tabir Kabupaten Merangin adalah tergolong tinggi yaitu $67,86 \%$ dari 28 responden dengan skor total 1.168. Faktor sosial ekonomi secara bersama-sama tidak berpengaruh terhadap keberhasilan produktivitas petani padi sawah di Desa Seling Kecamatan Tabir Kabupaten Merangin yang dapat dilihat dari nilai $\mathrm{F}$ hitung $(1,573)<\mathrm{F}$ Tabel $(2,796)$ dan secara parsial tingkat umur, tingkat pendidikan dan tingkat pendapatan sedangkan jumlah tanggungan
\end{abstract}


keluarga berpengaruh negatif tehadap keberhasilan produktivitas kerja petani sampel.

\title{
Kata Kunci : Faktor Sosial Ekonomi, Produktivitas, Petani Padi Saw
}

\begin{abstract}
This study aims to determine the productivity, socio-economic level and the influence of socio-economic factors on the productivity productivity of rice farmers in Seling Village, Tabir District, Merangin Regency. The research was carried out in the Seling village of the District of Tabir Merangin. The location of this study was done intentionally (purposive sampling) with the consideration that Seling village was the village with the highest success rate of paddy production compared to other villages in Tabir Subdistrict and the research was conducted from July to August 2018.

Research The method used in this study is the Survey method, where researchers examine the characteristics or causal relationships between variables without the intervention of researchers conducted with several stages of research, namely collecting survey data, analyzing data and testing hypotheses, and drawing conclusions. Withdrawal of sample farmers was carried out in a proportional random sampling of $10 \%$ of 276 wetland rice farmers, 28 rice farmers. The method of data analysis in this study is to use the productivity formula and by giving questions answered by respondents and the scores given are different for each answer available while to find out the relationship between socio-economic factors and productivity, multiple linear regression analysis using the SPSS program is used. .

The results showed that the productivity of lowland rice farmers in Seling Village, Tabir District, Merangin Regency was 1,996.44 Kg / Ha (1.99 tons / ha) with an average land area of $0.5 \mathrm{Ha}$ and produced an average production of 1,001.79 $\mathrm{Kg}$ while the socioeconomic level of wetland rice farmers in Seling Village, Tabir District, Merangin District is high, namely 67.86\% of 28 respondents with a total score of 1,168. The socio-economic factors together did not affect the productivity productivity of paddy farmers in Seling Village, Tabir District, Merangin District, which can be seen from the $F$ count (1.573) <F Table (2.796) and partially the age, education level and income level while the number of family dependents has a negative effect on the success of working productivity of sample farmers.
\end{abstract}

Keywords: Socio-Economic Factors, Productivity, Paddy Farmers

\section{PENDAHULUAN}

Sektor pertanian mempunyai peranan penting dalam perekono-mian Indonesia. Oleh karena itu,

pembangunan sektor pertanian
merupakan sektor penggerak
perkembangan ekonomi dan laju
pertumbuhan ekonomi. Dalam hal ini
sektor pertanian masih merupakan

salah satu sektor tumpuan yang diharapkan dalam proses pertumbu-hannya dapat memenuhi kebutuhan komsumsi masyarakat cenderung meningkat. Hal ini ditunjukkan dari banyaknya penduduk atau tenaga kerja yang hidup atau bekerja pada sektor pertanian serta produk nasional yang berasal dari pertanian, artinya pertanian memegang peranan penting dari keseluruhan 
perekono-mian nasional (Mubyarto, 1986).

Tujuan pembangunan perta-nian yaitu meningkatkan pendapatan petani, selain dari usaha untuk meningkatkan produksi juga dilaku-kan suatu system pemasaran hasil-hasil pertanian yang nantinya mampu menampung hasil pertanian yang dipasarkan, serta mampu berfungsi secara efisien. Petani memainkan peranan sebagai inti dalam pemba-ngunan pertanian. Petanilah yang memelihara tanaman dan menentu-kan bagaimana usaha taninya harus dimanfaatkan. Petanilah yang harus mempelajari dan menerapkan metoda-metoda baru yang diperlukan untuk membuat usaha taninya lebih produktif. (Mosher, 1985).

Sejak dulu, diantara tanaman bahan makanan, padi merupakan tanaman utama para petani Indone-sia. Padi/beras dianggap sebagai ko-moditi strategis yang dominan dalam ekonmi Indonesia karena beras meru-pakan makanan pokok sebagian be-sar rakyat Indonesia. Kebutuhan beras setiap tahun bertambah sesuai pertambahan jumlah penduduk yang terus meningkat dan juga karena kebutuhan per kapita meningkat. Meningkatnya kebutuhan per kapita disebabkan oleh beralihnya pendu-duk bukan pemakan beras menjadi pemakan beras sebagai makanan pokoknya (Adiratma, 2004).

Ditinjau dari segi produksi, berdasarkan data Kementerian Pertanian (2018) produksi padi pada 2017 naik 2,55 menjadi 81,38 juta ton berdasarkan Angka Ramalan (ARAM) II. Jumlah tersebut terdiri dari produksi padi sawah seberat 77,6 juta ton dan 3,78 juta ton padi ladang. Sementara luas lahan panen pada tahun lalu meningkat $4,17 \%$ menjadi 15,79 juta hektare (ha). Angka tersebut terdiri dari luas lahan untuk padi sawah seluas 14,63 ha dan lahan padi ladang 1,16 ha. Sementara produktivitas 51,55 Ku/ha. Sedangkan untuk Provinsi Jambi produksi padi sawah pada tahun 2015 mencapai 485.989 ton gabah giling kering dengan luas panen 102.207 ha (BPS Provinsi Jambi, 2016)

Salah satu daerah sentral penghasil padi di Provinsi Jambi adalah Kabupaten Merangin. Sektor tanaman pangan khusunya padi memegang peranan yang cukup penting dalam kehidupan masyarakat Kabupaten Merangin. Pada Tahun 2017 Kabupaten Merangin mampu memproduksi padi sawah sebesar 85.796 ton gabah giling kering dengan luas panen sebesar 15.900 Ha. Berdasarkan data Dinas Pertanian Tanaman Pangan dan Hortikultura Kabupaten Merangin (2017), Kecamatan Tabir merupakan Kecamatan yang mempunyai luas panen yang terluas yaitu seluas $3.449 \mathrm{Ha}$ dan produksi padi sawah yang terbanyak di Kabupaten Merangin yaitu sebanyak yaitu 20.316 Ton dengan produktivitas 5,89 ton/ha. Besarnya produksi padi sawah dan luasnya panen tanaman padi diKecamatan Tabir karena didukung oleh keadaan geografi kecamatan Tabir dimana desa-desa di Kecamatan Tabir yang menanam padi pada umumnya berada di pinggir sungai Tabir. Dari 11 desa yang ada di Tabir, hanya 8 desa yang memproduksi padi sawah dan desa Dusun Baru adalah desa dengan luas tanam terluas yaitu $1.135 \mathrm{Ha}$ dan diikuti oleh desa Seling dengan luas tanam 995 Ha dan produtivitas tertinggi yaitu 6,30 ton/ha dan tingkat keberhasilan 98,91 $\%$. Tingkat keberhasilan didapat dari perbandingan antara luas tanam padi sawah dengan luas panen padi sawah, sehingga dengan luas lahan yang tinggi dan tingkat keberhasilan yang tinggi ini pantas untuk di teliti karena tingginya tingkat keberhasilan petani padi sawah di Desa Seling ini tentu tidak terwujud 
dengan sendirinya melainkan kerja keras dari petani tersebut.

Adapun tujuan dari penelitian ini adalah untuk mengetahui produktivitas petani petani padi sawah, tingkat sosial ekonomi (umur, tingkat pendidikan, tanggungan keluarga dan tingkat pendapatan) petani padi sawah dan untuk megetahui pengaruh faktor sosial ekonomi (umur, tingkat pendidikan, tanggungan keluarga dan tingkat pendapatan) terhadap keberhasilan produktivitas petani padi sawah di Desa Seling Kecamatan Tabir Kabupaten Merangin.

Tingginya tingkat keberhasi-lan petani padi sawah dalam meningkatkan produksi padi sawah di desa Seling tentu dipengaruhi oleh banyak faktor, salah satunya adalah faktor sosial ekonomi yang ada disekitarnya. Faktor sosial ekonomi adalah faktor-faktor yang berasal dari segi sosial dan ekonomi yang dimiliki petani sehingga dapat mempengaruhi pandangan mereka mengenai suatu hal. Soekartawi (2002) juga menyatakan produksi pertanian dipengaruhi oleh berbagai faktor salah satunya adalah faktor sosial ekonomi produsen.

Berdasarkan uraian dari latar belakang diatas, penulis tertarik untuk melakukan penelitian yang berjudul 'Faktor-Faktor Sosial Ekonomi yang Mempengaruhi Keberhasilan Produktivitas Petani Padi Sawah Di Desa Seling Kecamatan Tabir Kabupaten Merangin"

\section{METODOLOGI PENELITIAN}

Metode yang digunakan dalam penelitian ini adalah metode Survei, yaitu metode penelitian yang dilaksanakan untuk memperoleh faktafakta dan gejala yang ada dan mencari keterangan secara faktual, baik tentang institusi sosial atau ekonomi dari suatu kelompok ataupun suatu daerah. Metode ini digunakan untuk mengetahui dan mendapatkan kebenaran terhadap keadaan dan praktek - praktek yang sedang berlangsung (Nazir, 1998). Dalam penelitian survey, peneliti meneliti karakteristik atau hubungan sebab akibat antar variabel tanpa adanya intervensi peneliti.

Adapun metode analisis data yang digunakan adalah untuk menghitung besarnya tingkat keberhasilan produktivitas petani padi sawah digunakan rumus : (Widodo, 1989) :

Produktivitas $=\underline{\text { Jumlah Hasil Produksi }(\mathrm{Kg})}$ Luas Lahan (Ha)

Untuk mengetahui faktor sosial ekonomi petani padi sawah, peneliti memberikan pertanyaan yang dijawab oleh responden dan skor yang diberikan berbeda untuk setiap jawaban yang tersedia. Pilihan jawaban yang paling positif yaitu jawaban A diberikan skor tertinggi yaitu 5, sedangkan untuk pilihan jawaban $\mathrm{B}$ dan $\mathrm{C}$ masingmasing diberi skor 3 dan 1 . Skor untuk masing-masing responden dijumlahkan untuk mengetahui faktor sosial ekonomi responden tersebut.

Adapun jumlah kategori dalam faktor sosial ekonomi adalah sebanyak dua kelas yaitu Tinggi dan rendah, maka menurut Suparman (1990), interval kelas dapat ditentuk agai berikut:

$$
\mathrm{C}=\frac{\mathrm{x}_{\mathrm{n}}-\mathrm{x}_{\mathrm{i}}}{\mathrm{K}}=\frac{60-12}{2}=24
$$

Dimana :

$\mathrm{C}=$ Interval Kelas

$\mathrm{X}_{\mathrm{n}}=$ Skor Maksimum

$X_{i}=$ Skor Minimum

$\mathrm{K}=$ Jumlah Kelas 
Hasil perhitungan tersebut digunakan untuk menentukan kategori tingkat sosial ekonomi petani padi sawah, yaitu :

- Skor 36 - 60 tingkat faktor sosial ekonomi tinggi

- Skor 12 - 35 tingkat faktor sosial ekonomi rendah

Hasil 35 didapat dari $24+12-1$

$=35$ untuk mengetahui selisih

interval

Sedangkan untuk menguji faktor-faktor sosial ekonomi yang mempengaruhi produktivitas petani padi sawah maka digunakan metode analisis regresi linier berganda dengan menggunakan program SPSS karena program tersebut lebih mudah diaplikasikan dan dianalisis oleh penulis. Menurut Soekartawi (2002), secara matematis dapat ditulis sebagai berikut :

$Y=a+b_{1} X_{1}+b_{2} X_{2}+b_{3} X_{3}+b_{4} X_{4}+e$

Keterangan:

$\mathrm{Y} \quad=$ Produktivitas

$\mathrm{X}_{1} \quad=$ Tingkat Umur

$\mathrm{X}_{2} \quad=$ Tingkat Pendidikan

$\mathrm{X}_{3} \quad=$ Tanggungan Keluarga

$\mathrm{X}_{4} \quad=$ Tingkat Pendapatan

a $\quad=$ Intersep

$\mathrm{b}_{1} . . \mathrm{b}_{4}=$ Koefisien regresi dari $\mathrm{X}_{1}, \mathrm{X}_{2}$, $\mathrm{X}_{3}, \mathrm{X}_{4}$

Untuk mengetahui besarnya proporsi atau presentase variasi produtivitas petani padi sawah yang dijelaskan oleh setiap variabel secara bersama-sama, digunakan koefisien determinasi $\left(\mathrm{R}^{2}\right)$ dengan rumus :

$$
\mathrm{R}^{2}=\frac{\text { bi } \sum \mathrm{XiYi}}{\sum \mathrm{Yi}^{2}}
$$

Dimana :

$\mathrm{R}^{2}=$ Koefisien determinasi ber-ganda antara Yi dengan $\mathrm{Xi}$

bi $=$ Koefisien regresi ke- $\mathrm{i}$
$\mathrm{Yi}^{2}=$ Kuadrat simpangan suatu variabel ke-I dari nilai rata-rata $(\mathrm{Yi}-\mathrm{Y})^{2}$

$\mathrm{Xi}=$ Variabel deviasi ke-i dari ratarata $(\mathrm{Xi}-\mathrm{X})$

$\mathrm{Yi}=$ Simpangan suatu variabel dari nilai rata-rata (Yi-Y)

Untuk pengujian kebenaran dari seluruh variabel digunakan pengujian Ftest, Nilai dihitung dengan rumus :

$$
\mathrm{F}_{\text {hitung }}=\frac{\mathrm{R}^{2} / \mathrm{k}}{\left(1-\mathrm{R}^{2}\right) /(\mathrm{n}-\mathrm{k}-1)}
$$

Dimana :

$\mathrm{R}^{2} \quad=$ Koefiien Determinasi

$\mathrm{k} \quad=$ Jumlah variabel

$\mathrm{n} \quad=$ Jumlah sampel

Jika $\mathrm{F}_{\text {hitung }} \geq \mathrm{F}_{\text {table }}$ berarti $\mathrm{H}_{0}$ ditolak, dan

Jika $\mathrm{F}_{\text {hitung }}<\mathrm{F}$ tablel berarti $\mathrm{H}_{0}$ diterima, (Sudjana, 2008)

Ho : Tidak terdapat hubungan antara faktor-faktor sosial ekonomi dengan keberhasilan produtivitas petani padi sawah

$\mathrm{H}_{1}$ : Terdapat hubungan antara faktor sosial ekonomi denagan keberhasilan produtivitas petani padi sawah

Sedangkan untuk uji individu atau parisal digunakan uji T, (Sudjana, 2008) dengan rumus sebagai berikut :

$$
\mathrm{Ti}=\frac{\mathrm{bi}}{\text { Sbi }}
$$

Dimana :

$\mathrm{Ti}=\mathrm{t}$-hitung

bi $=$ Koefisien regresi variabel ke -1

Sbi $=$ Standar error masing-masing variabel ke-1

Jika $\mathrm{t}_{\text {hitung }}<\mathrm{t}_{\text {table }}$ berarti $\mathrm{H}_{1}$ ditolak, dan Jika $t_{\text {hitung }} \geq t$ tablel berarti $\mathrm{H}_{1}$ diterima, (Sudjana, 2008)

\section{HASIL DAN PEMBAHASAN}

\section{Identitas Petani Responden}




\section{a) Umur Responden}

Dalam menyusun distribusi frekuensi, digunakan langkah-langkah berdasarkan pada Sugiyono (2012) yaitu untuk menentukan jumlah kelas interval, digunakan rumus Sturges yakni jumlah kelas interval $=1+3,3 \log n$. Dimana $\mathrm{n}$ adalah jumlah responden. Sehingga presentase umur yang paling tinggi adalah petani sampel yang mempunyai umur antara 43 - 49 tahun yaitu sebanyak 10 orang atau $35,71 \%$, dan diikuti oleh petani sampel pada umur $50-56$ tahun sebanyak 8 orang atau $32,14 \%$, dan petani umur $22-28$ tahun merupakan distrbusi umur responden yang paling sedikit yaitu sebanyak 1 orang atau 3,57\%. Hal ini menunjukkan bahwa hampir semua golongan umur tertarik untuk berusahatani padi, dan dapat dikatakan bahwa responden yang diteliti pada umumnya berada pada umur produktif. Karena Menurut Soeharjo dan Patong (1984), bahwa katagori umur produktif adalah mulai dari usia 15-54 tahun dan selebihnya masuk katagori umur non produktif. Dengan adanya distribusi dan frekuensi responden berdasarkan umur ini dapat diketahui pada kisaran umur berapa peminat masyarakat di bidang pertanian, terutama pada budidaya padi.

\section{b) Tingkat Pendidikan}

Berdasarkan hasil penelitian diketahui bahwa petani tidak ada yang buta huruf karena semuanya pernah duduk di sekolah formal, tetapi tingkat pendidikan mayoritas tergolong sedang yakni sebanyak 16 orang $(57,14 \%)$ hanya tamat SD dan 4 orang $(14,29 \%)$ tamat SMP, 5 orang $(17,86 \%)$ berpendidikan SMA dan hanya 3 orang $(10,71 \%)$ berpendidikan D3/S1. Sehingga responden ditempat penelitian tergolong rendah. Dengan pendidikan yang dimiliki, diharapkan responden bisa memberikan respon cukup baik terhadap hal yang baru guna mengembangkan usaha mereka.

Tingkat pendidikan petani akan mempengaruhi cara berfikir petani dalam mengelola usaha taninya yaitu dalam hal kemampuan mengelola usahatani dan menerima inovasi baru. Pernyataan ini sesuai dengan pendapat Hernanto (2006), tingkat pendidikan akan mempengaruhi cara berfikir menerima dan mencoba hal baru. Pendidikan juga mempunyai hubungan positif dengan aspirasi seseorang yang pada akhirnya akan menentukan seseorang mengambil keputusan.

\section{c) Jumlah Tanggungan Keluarga}

Jumlah tanggungan keluarga yang dimaksud dalam penelitian ini adalah semua orang yang tinggal dalam satu rumah atau jumlah jiwa yang kebutuhan fisik dan batinnya menjadi tanggungan petani. Besarnya jumlah tanggungan keluarga akan berhubungan dengan ketersediaan tenaga kerja untuk kegiatan usahataninya dan disamping itu dapat mendorong petani untuk bekerja lebih giat guna memenuhi kebutuhan hidup anggota keluarga tersebut. Berdasarkan Tabel 11 di atas dapat dijelaskan bahwa sebanyak 9 orang responden $(32,14 \%)$, responden memiliki tanggungan keluarga sebanyak 4 orang dan jumlah hanya 3 oranng $(10,71 \%)$ responden yang mempunyai jumlah tanggungan keluarga yang besar (6 orang)

Jumlah anggota keluarga yang besar tidak selamanya merupakan modal bagi keluarga tetapi dapat juga menjadi beban bagi keluarga sebab tidak semua anggota keluarga merupakan tenaga yang produktif. Besar kecilnya jumlah anggota keluarga dalam suatu rumah tangga menunjukkan besar kecilnya beban tanggungan yang harus dipikul oleh peetani sebagai kepala keluarga. Jumlah anggota 
keluarga yang banyak juga dapat menunjang ekonomi keluarga. Semakin besar jumlah anggota rumah tangga, dapat menunjang ekonomi keluarga karena dapat terlibat pada berbagai kegiatan produktif, misalnya terlibat dalam proses produksi hingga pascapanen. Sejalan dengan hal tersebut, anak-anak dibawah umur, orang lanjut usia dan ibu rumah tangga walaupun menjadi beban kepala keluarga namun sedikit tidaknya mereka melibatkan diri membantu dalam usahatani padi sawah.

\section{d) Luas Lahan}

Petani responden di lokasi penelitian memiliki luas lahan yang bervariasi. Para petani responden memiliki luas lahan antara 0,12-1 $\mathrm{Ha}$ dengan rata-rata luas lahan responden adalah 0,5 Ha. Luas lahan mempengaruhi hasil produksi namun luasan lahan harus juga seimbang dengan tingkat perawatan sehingga akan meningkatkan produksi. Hernanto (2006) menyebutkan, luas lahan usahatani menetukan pendapatan, taraf hidup dan derajat kesejahteraan rumah tangga tani.

\section{Produktivitas Padi Sawah}

Produktivitas adalah produksi yang dihasilkan oleh petani per luasnya lahan yang diusahakan oleh petani. Berdasarkan data kuisioner menerangkan bahwa rata-rata produksi padi sawah dalam satu kali musim tanam yang dihasilkan oleh petani padi di desa Seling adalah berkisar antara $300 \mathrm{Kg}-2.000 \mathrm{Kg}$ dengan rata-rata luas lahan berkisar antara sebesar 0,12 Ha - 1 Ha. Dimana produktivitas tanaman padi sawah dengan luas lahan rata-rata $0,5 \mathrm{Ha}$ dan menghasilkan ratarata produksi sebanyak $1.001,79 \mathrm{Kg}$ per petani sehingga dipatkan produktivitas sebanyak 1.996,44 Kg/Ha (1,99 ton/Ha).

\section{Faktor Sosial Ekonomi Petani Sampel}

Dalam penelitian ini, faktor sosial ekonomi petani padi sawah di desa Seling dalam berusahatani padi sawah secara umum tergolong tinggi, dengan kriteria pengukuran scara keseluruhan responden yaitu : 1.0081.680 faktor sosial ekonomi tinggi dan 672 - 1.007 faktor sosial ekonomi rendah. Berdasarkan kriteria tersebut maka didapat bahwa faktor sosial total petani sampel di desa Seling yaitu sebesar 1.168 baerada pada interval 1.008- 1.680 dengan kriteria faktor sosial ekonomi tinggi. Adapun faktor sosial ekonomi tersebut adalah umur, tanggungan keluarga, tingkat pendidikan dan tingkat pendapat.

\section{1) Umur}

Berdasarkan hasil olahan data diperoleh distribusi dan frekuensi umur responden dalam berusahatani padi sawah di desa Seling mempunyai tingkat umur dengan kriteria tinggi yaitu $82,29 \%$ dan hanya $10,71 \%$ yang memiliki respon umur yang rendah dalam berusahatani padi sawah hal ini karena petani padi pada umumnya berada pada usia produktif. Pada umur produktif pada umumnya seseorang masih dimungkinkan memiliki keinginan untuk meningkatkan keterampilan dan menambah pengetahuan dalam mengelolah usahanya. Meningkatnya keterampilan dan pengetahuan masyarakat secara tidak langsung dapat mempengaruhi produksi padi sawah. Umur petani akan mempengaruhi kemampuan fisik dan respon terhadap hal-hal yang baru dalam menjalankan usahataninya. Menurut Soekartawi (1988) makin muda petani biasanya semangat untuk ingin tahu apa yang belum mereka ketahui, dengan demikian mereka berusaha untuk lebih cepat melakukan 
adopsi inovasi walaupun sebenarnya mereka masih belum berpengalaman dalam hal adopsi inovasi

\section{2) Tingkat Pendidikan}

Berdasarkan hasil olahan data diperoleh distribusi dan frekuensi tingkat pendidikan dalam keberhasilan produktivitas petani padi sawah desa Seling memperlihatkan bahwa sebanyak 20 orang atau $71,43 \%$ responden memiliki respon yang tinggi terhadap tingkat pendidikan dan hanaya 8 orang $(28,5 \%)$ responden berada pada respon yang rendah terhadap tingkat pendidikan. Dalam penelitian ini telah diketahui bahwa tingkat pendidikan responden sebagian besar hanya tamat SD dan tergolong sedang. Namun mereka meyakini bahwa dengan pendidikan ini jelas mempengaruhi kehidupan mereka terutama permasalahan di dalam bidang pekerjaan yang ditekuni, dari kecil mereka terdidik untuk menganut pola bermasyarakat secara tradisonal dan cenderung mengikuti orang tua mereka yang memanfaatkan sawah untuk bercocok tanam sebagai sumber penghasilan utama dalam kehidupan sehari-hari mereka.

Petani yang pendidikannya lebih tinggi biasanya lebih dinamis, cepat dan tepat dalam pengambilan keputusan dari setiap alternatif usahanya dibandingkan dengan petani yang tingkat pendidikannya lebih rendah tetapi dapat juga terjadi kemungkinan petani yang mempunyai pendidikan lebih rendah tepat dalam pengambilan keputusan. Hal ini karena mereka memiliki pengalaman yang lebih dalam berusahatani. Menurut Sajogyo dan Pudjiwati (2011) pengalaman merupakan pengetahuan yang dialami seseorang dalam kurun waktu yang tidak ditentukan. Hernanto (2006) menyatakan, bahwa keterbatasan tingkat pendidikan akan mempengaruhi cara berfikir, menerima, mencoba ataupun menolak hal-hal baru

\section{3) Tingkat Tanggungan Keluarga}

Berdasarkan hasil olahan data diperoleh distribusi dan frekuensi tanggungan keluarga dalam keberhasilan produktivitas petani padi sawah desa Seling sebagian besar yaitu $57,14 \%$ (16 orang) responden tingkat tanggungan keluarga berkriteria rendah dan hanya $42,86 \%$ (12 orang) responden beranggapan tanggungan keluarga tinggi berkontribusi dalam meningkatkan produktivitas petani padi sawah hal ini disebabkan jumlah tanggungan petani sampel didominasi oleh jumlah tanggungan 2-4 orang, selain itu rendahnya kriteria tanggungan keluarga responden karena usahatani padi sawah belum cukup untuk memenuhi tanggungan keluarga yang dimiliki, yang berarti bahwa responden akan tetap bekerja keras dalam mengelola usahataninya untuk memenuhi seluruh kebutuhan keluarganya meskipun tanggungan keluarga yang dimiliki kecil atau sedikit. Menurut Hernanto (2006), bahwa seseorang yang mempunyai jumlah tanggungan yang lebih besar akan diburu oleh kebutuhan keluarga, dengan demikian mereka akan berusaha semaksimal mungkin untuk memenuhi kebutuhannya.

\section{4) Tingkat Pendapatan}

Pendapatan yang dimaksud dalam penelitian adalah pendapatan yang diperoleh petani sampel dalam berusahatani padi sawah yang berguna untuk memenuhi kebutuhan hidup. Adapun persepsi responden terhadap tingkat pendapatan usahatani padi sawah, $50 \%$ orang (14 orang) responden memiliki respon yang rendah terhadap tingkat pendapatan dalam berusahatani padi sawah dan $50 \%$ (14 orang) lagi responden juga memiliki respon yang tinggi terhadap tingkat 
pendapatan dalam berusahatani padi sawah.. Hal ini menggambarkan bahwa tingkat pendapatan petani sampel dalam berusahatani padi sawah tidak tinggi dan tidak pula rendah yang berarti bahwa responden berada pada kelas ekonomi menengah. Hal ini lebih ddisebabkan oleh luas lahan yang dimiliki karena dengan luas lahan yang dimiliki responden masih kecil sehingga kurang berkonsentrasi dalam berusahatani padi sawah. Menurut Yatno, dkk (2003) petani yang mempunyai tingkat pendapatan lebih tinggi akan mempunyai kesempatan yang lebih untuk memilih tanaman daripada yang berpendapatan rendah. Bagi petani yang mempunyai pendapatan yang kecil tentu tidak berani mengambil resiko karena keterbatasan modal.

\section{3) Hubungan Faktor Sosial Eko- nomi terhadap Keberhasilan Produktivitas Padi Sawah}

Data yang digunakan untuk menganalisis faktor-faktor yang mempengaruhi keberhasilan produktivitas padi sawah adalah data produksi padi sawah yang diusahakan selama satu kali produksi di desa Seling. Analisis yang digunakan adalah analisis regresi linear berganda, dengan menggunakan program SPSS karena program tersebut lebih mudah diaplikasikan dan dianalisis oleh peneliti. Hasil analisis faktor-faktor yang mempengaruhi keberhasilan produktivitas petani padi sawah disajikan pada Tabel 1.

Tabel 1. Hasil Analisis Regresi Berganda pada Faktor-faktor yang Mempengaruhi Keberhasilan Produktivitas Padi sawah di Desa Seling

\begin{tabular}{|c|c|c|c|c|c|c|}
\hline No & Variabel & $\begin{array}{l}\text { Koefisien } \\
\text { Regresi } \\
\text { (B) }\end{array}$ & $\begin{array}{c}\text { Standar } \\
\text { Error (SB) }\end{array}$ & Beta & t hitung & t table \\
\hline 1. & (Constant) & 1272.880 & 1026.067 & & 1.241 & \multirow{5}{*}{2.069} \\
\hline 2. & Umur & 159.573 & 98.132 & .386 & 1.626 & \\
\hline 3. & Tanggungan Keluarga & -153.398 & 73.953 & -.556 & -2.074 & \\
\hline 4. & Tingkat Pendidikan & 6.622 & 106.891 & .030 & .062 & \\
\hline 5 & Pendapatan & 38.379 & 91.544 & .197 & .419 & \\
\hline & $\mathrm{R}^{2}$ & .215 & & & & \\
\hline & F hitung & 1,573 & & & & \\
\hline & F table & 2,796 & & & & \\
\hline
\end{tabular}

Sumber : Hasil Analisis Regresi

Pada Tabel diatas diperoleh nilai koefisien determinasi $\left(\mathrm{R}^{2}\right)$ sebesar 0,215 yang artinya bahwa variabel independen (faktor sosial ekonomi) yang digunakan dalam model hanya mampu menjelaskan variabel dependen (produktivitas padi sawah) sebesar $21,5 \%$ dan sisanya sebesar $78,5 \%$ lagi dijelaskan oleh variabel (faktor) lain yang tidak dimasukkan dalam model. Dari nilai $F$ hitung $(1,573)<$ nilai $F$ tabel $(2,796)$ yang artinya bahwa variabel independent atau faktor sosial ekonomi (umur, Tanggungan keluarga, Tingkat pendidikan dan pendapatan) secara bersama-sama tidak berpengaruh dalam keberhasilan produktivitas 
petani padi sawah yang diperoleh. Persamaan regresi yang diperoleh dari hasil analisis model fungsi produksi Cobb Douglas adalah :

$$
\mathrm{Y}=1272.880+159.573 \mathrm{X}_{1}-
$$

$153.398 X_{2}+6.622 X_{3}+38.379 X_{4}$

Selanjutnya untuk mengetahui pengaruh masing-masing variabel independen (X) terhadap variabel dependen (Y) dilakukan analisis individu atau parsial uji $t$ terhadap koefisien regresi, dilihat dari nilai $\mathrm{t}$ hitung secara individu, umur, tanggungan keluarga, tingkat pendidikan dan persepsi terhadap pendapatan. Dari model regresi yang dihasilkan, diperoleh nilai t hitung 1.626 dan nilai $t$ tabel 2.069. Data ini menjelaskan bahwa t hitung < $\mathrm{t}$ tabel pada tingkat kepercayaan $95 \%$ sehingga terima $\mathrm{Ho}$ dan tolak $\mathrm{H}_{1}$. Berarti umur secara individu tidak berpengaruh terhadap keberhasilan produktivitas padi sawah di desa Seling. Selain itu pada tingkat kepercayaan $95 \%$ jika variabel lain dianggap konstan maka setiap penambahan satu satuan umur reponden maka tidak akan diikuti oleh peningkatan keberhasilan produktivitas sebesar 159.573. Hal ini karena produktivitas kerja petani padi sawah hanya sampai batas umur tertentu saja dimana selanjutnya jika umur bertambah maka produktivitas menurun. Penurunan ini disebabkan oleh kondisi fisik dan kesehatan akan menurun seiring bertambahnya umur sehingga berdampak menurunnya keberhasilan produktivitas petani padi sawah.

Dari model regresi yang dihasilkan, diperoleh nilai koefisien regresi tanggungan keluarga yang digunakan pada analisis produktivitas padi sawah yang terdapat pada Tabel 1 adalah sebesar -153.398 dengan nilai t hitung -2.074 dan nilai t tabel 2,069. Data ini menjelaskan bahwa t hitung $>\mathrm{t}$ tabel sehingga $\mathrm{H}_{1}$ diterima dan tolak Ho yang berarti tanggungan keluarga pada tingkat kepercayaan $95 \%$ berpengaruh terhadap keberhasilan produktivitas padi sawah.

Tanda negatif pada model menjelaskan jika dilakukan penambahan tanggungan keluarga sebesar satu satuan akan mengurangi keberhasilan produktivitas sebesar 153.398 dan nyata pada taraf kepercayaan 95\% hal ini karena pada daerah penelitian jumlah tanggungan keluarga berkisar antar 2-6 orang, dan belum dapat dimafaatkan serta berkontribusi atau belum ikut serta membantu dalam proses usahatani padi sawah. Subagio (2011) juga mengatakan bahwa semakin banyak tanggungan keluarga, semakin banyak ketersediaan tenaga kerja untuk usahatani. Apabila tanggungan keluarga tersebut tidak dapat menyumbangkan tenaganya, maka akan berdampak negatif terhadap usahataninya. Anggota keluarga yang tidak menyumbangkan tenaganya akan menjadi beban bagi petani.

Ditinjau dari tingkat pendidikan, diperoleh nilai t hitung .062 dan nilai $t$ tabel 2,069. Data ini menjelaskan bahwa t hitung $<\mathrm{t}$ tabel pada tingkat kepercayaan $95 \%$ sehingga terima $\mathrm{Ho}$ dan tolak $\mathrm{H}_{1}$. Berarti pendidikan secara individu tidak berpengaruh terhadap keberhasilan produktivitas padi sawah di desa Seling. Selain itu pada tingkat kepercayaan $95 \%$ jika variabel lain dianggap konstan maka setiap penambahan satu jenjang pendidikan responden maka tidak akan diikuti dengan peningkatan keberhasilan produktivitas petani padi sawah. Hal ini karena pendidikan yang dimiliki 
responden masih tergolong rendah sehingga tidak memberikan respon cukup baik terhadap hal yang baru guna mengembangkan usaha mereka, dan responden sudah merasa cukup atau puas dengan pendidikan yang dimiliki sehingga tidak mempengaruhi keberhasilan produktivitas petani padi sawah. Menurut Simanjuntak, (2005) semakin tinggi tingkat pendidikan seseorang maka semakin tinggi juga tingkat produktivitas. Lebih lanjut Woyanti (2012) menjelaskan bahwa pada umumnya orang yang mempunyai pendidikan formal maupun informal yang lebih tinggi akan mempunyai wawasan yang lebih luas. Tingginya kesadaran akan pentingnya produktivitas, akan mendorong tenaga kerja yang bersangkutan melakukan tindakan yang produktif.

Untuk tingkat pendapatan, diperoleh nilai $\mathrm{t}$ hitung 0,419 dan nilai $t$ tabel 2,069. Data ini menjelaskan bahwa t hitung < t tabel pada tingkat kepercayaan $95 \%$ sehingga terima $\mathrm{Ho}$ dan tolak $\mathrm{H}_{1}$. Berarti tingkat pendapatan secara individu juga tidak berpengaruh terhadap keberhasilan produktivitas padi sawah di desa Seling. Selain itu pada tingkat kepercayaan 95\% jika variabel lain dianggap konstan maka setiap penambahan satu satuan pendapatan repsonden maka tidak akan diikuti dengan peningkatan keberhasilan produktivitas petani padi sawah. Hal ini berhubungan dengan luas lahan garapan responden sempit dan keluarga yang ditanggung belum memberikan kontribusi dan menjadi beban petani padi sawah sehingga dalam menggarap lahan padi sawah petani mengeluarkan biaya yang banyak terhadap tenaga kerja yang berdampak terhadap pendapatan yang diterima rendah bahkan hasil panen hanya cukup untuk memenuhi kebutuhan keluarga yang ditanggung sehingga pendapatan tidak mempengaruhi produktivitas petani padi sawah di desa Seling.

\section{KESIMPULAN DAN SARAN}

\section{Kesimpulan}

1. Produktivitas petani padi sawah di Desa Seling Kecamatan Tabir Kabupaten Merangin adalah $1.996,44 \mathrm{Kg} / \mathrm{Ha} \quad(1,99$ ton/Ha) dengan luas lahan rata-rata 0,5 Ha dan menghasilkan rata-rata produksi sebanyak $1.001,79 \mathrm{Kg}$

2. Tingkat sosial ekonomi petani padi sawah di Desa Seling Kecamatan Tabir Kabupaten Merangin adalah tergolong tinggi yaitu $67,86 \%$ dari 28 responden dengan skor total 1.168

3. Faktor sosial ekonomi seacara bersama-sama tidak berpengaruh terhadap keberhasilan produktivitas petani padi sawah di Desa Seling Kecamatan Tabir Kabupaten Merangin karena nilai $\mathrm{F}$ hitung $(1,573)<\mathrm{F}$ Tabel $(2,796)$ dan secara individu atau parsial tingkat umur, tingkat pendidikan dan tingkat pendapatan tidak berpengaruh terhadap keberhasilan produktivitas padi sawah di desa Seling, sedangkan jumlah tanggungan keluarga berpengaruh negatif artinya jika dilakukan penambahan tanggungan keluarga sebesar satu satuan akan mengurangi keberhasilan produktivitas padi sawah di desa Seling sebesar koefisien regresi.

\section{Saran}


1. Mengingat desa Seling memiliki agroklimat yang sangat mendukung terhadap padi sawah, maka buat petani disarankan untuk lebih berkonsentrasi terhadap usahatani padi sawah melalui aktif dalam kelompok tani maupun gabungan kelompok tani.

2. Buat pemerintahan desa Seling disarankan untuk lebih memperhatikan kemakmuran petani padi sawah melalui penyuluhanpenyuluhan maupun bantuanbantuan alat-alat pertanian sehingga pendapatan petani padi sawah menjadi lebih baik lagi sehingga produktivitas padi sawah lebih meningkat.

\section{DAFTAR PUSTAKA}

Adiratma, E.R. 2004. Stop Tanam Padi?. Penebar Swadaya, Jakarta

Arikunto, S. 2006. Prosedur Penelitian. PT. Rineka Cipta: Jakarta

BPS Provinsi Jambi, 2016. Produksi Padi Provinsi Jambi 2015. http://jambi.bps.go.id.

Diunduh Mei 2018

Dinas Pertanian Tanaman Pangan dan Hortikultura Kabupaten Merangin. 2017. Luas Panen, Produksi dan Rata-rata Produksi Padi Sawah Menurut Kecamatan di Kabupaten Merangin tahun 2016. Bangko

Hernanto, F. 2006. Ilmu Usahatani. Penebar Swadaya. Jakarta.

Kementerian Pertanian. 2018. Petunjuk Teknis Pelaksanaan
Kegiatan Budidaya Padi

Tahun 2018. Direktur Tanaman Pangan. Jakarta

Mubyarto, 1989. Pengantar Ekonomi Pertanian. LP3ES. Jakarta.

Nazir, M. 1998. Metode Penelitian. Ghalia Indonesia. Jakarta.

Sajogyo dan Pudjiwati. 2011. Sosiologi Pedesaan. Gadjah Mada University Press. Yogyakarta.

Simanjuntak, P.J. 2005. Pengantar Ekonomi Sumber Daya Manusia. LP - FE,UI. Jakarta

Soeharjo A. dan Dahlan Patong, 1984. Sendi-sendi Pokok Ilmu Usahatani. Depatemen Ilmu-ilmu Sosial Ekonomi Faperta, IPB, Bogor.

Soekartawi. 1988. Prinsip Dasar Komunikasi Pertanian.UI Press.Jakarta

Soekartawi. 2002. Prinsip Dasar Ekonomi Pertanian. Teori dan Aplikasi. Rajawali Press. Jakarta

Subagio, H. C. NM. 2011. Hubungan Karakteristik Petani dengan Usahatani Cabai sebagai Dampak dari Pembelajaran FMA (Studi Kasus di Desa Sunju Kecamatan Marawola Provinsi Sulawesi Tengah). Balai Pengkajian Teknologi Pertanian Sulawesi Tengah

Sudjana, 2008. Metode Statistik. Tarsito. Bandung 
Sugiyono. 2012. Metode Penelitian

Kuantitatif Kualitatif \& RND.

Alfabeta. Bandung

Suparman, I. 1990. Statistik sosial.

Rajawali Pres, Jakarta.

Widodo, U.W. 1989. Produktivitas Tenaga Kerja, Jurnal Lintasan Ekonomi Volume 6. No. 2.

Woyanti, N. 2012. Analisis Pengaruh Pendidikan, Upah, Insentif, Jaminan Sosial Dan Pengalaman Kerja Terhadap Produktivitas Tenaga Kerja Di Kota Semarang (Studi Kasus Kec. Banyumanik Dan Kec. Gunungpati). Diponegoro Journal Of Economics. Volume 1, Nomor 1, Tahun 2012, Halaman 1-11. 